\title{
A Study on Women Empowerment and Entrepreneurial Intention among Small Business of Women Entrepreneurs in the Czech Republic
}

\author{
J. Jose Prabhu
}

Department of Business Management, Management and Engineering College, Tamil Nadu, India

\begin{abstract}
Entrepreneurship refers to establishing of a brand-new business to take advantages from brand-new chances. Entrepreneur is the vital element of entrepreneurship and also now women in Czech Republic are additionally effective in this as they have qualities preferable for entrepreneurship advancement. Entrepreneurship is a much ideal profession for women than regular work. Females are thought about an important human resource of the country and every state need to try to utilize them as arbitrators of economic growth and also advancement. Empowerment of women has actually become a vital concern in current times. This write-up manages empowerment of country females via entrepreneurship as well as the benefits entrepreneurship among the small company. "Economic empowerment of females resulted in development of household as well as Neighborhood". This principle purpose of the research study is to identify the economic empowerment of women business owners. The example size of the study is 100 respondents. The data collected went through online form structured questionnaire as well as the devices utilized for analysis percentage analysis and also ANOVA test. This declaration is confirmed by a cumulative small business entrepreneurship in the Czech Republic.
\end{abstract}

Keywords: Entrepreneurship, Entrepreneurial Intention, Women Empowerment, Economic Development, Small Business Growth, Czech Republic.

\section{Introduction}

The terms "Entrepreneurs" and also "Entrepreneurship" plays vital roles in today's global company setting. Media like papers, journals, magazines, TV channels, radio etc, also really typically bring out the effective tales of business owners. The principle of entrepreneurship has come to be a preferred topic these days.

Belás, et al (2017) The "Entrepreneurship explains the process and also activities embarked on by business owners. Entrepreneurs are people that organize, run, and presume the dangers related to a company endeavor they develop in pursuit of an opportunity them and also others have actually recognized. Entrepreneurship as a distinctive variable of manufacturing adds to the economic development of an economic situation. Its contributions to the economic growth consist of promotion of funding formation, creation of immediate huge scale work, promotion of balanced regional advancement, reliable mobilization of funding and also a skill, induction of in reverse and also ahead affiliations and so on.

Lukeš (2017) Entrepreneurship increases the financial growth of a country. Its duty is more crucial in creating countries. Comprehending the relevance of promoting entrepreneurial spirit among the people, both main and state governments have actually set up numerous organizations. Various management institutions, colleges, and autonomous universities additionally have actually incorporated Entrepreneurial Development in their educational program so as to offer needed exposure to the trainees regarding the business as well as the industrial environment of the nation.

\footnotetext{
* Corresponding author.

E-mail address: drjose999@gmail.com (J. Jose Prabhu)
} 


\subsection{Entrepreneurship in Czech Republic}

Belas, et al (2019) Women had organizations that are highly increasing in the economic climates of almost all nations. The hidden business capacities of women have slowly been changing with the expanding level of sensitivity to the duty and economic status in the society. Ability, Understanding, and also versatility in organizations are the major factors for women to emerge into business ventures. "Women Entrepreneur" is an individual who approves tough function to fulfill her individual needs and also end up being economically independent. The federal government gradually thinks about entrepreneurship and development to be the keystones of a competitive national economy, and also in many nations entrepreneurship policies are in truth very closely attached to advancement plans, with which they share several qualities and also difficulties. Lady constitutes the family members, which causes Culture as well as Country. Women business owners make considerable contributions to financial growth as well as to destitution reduction. The theoretical paper showed the duty and stressed the women entrepreneurs as the potentially arising personnel in the 21 st century to overcome the economic challenges from a global point of view. Females have actually been taking boosting passion in the last few years in income-producing activities, self-employment and also entrepreneurship. It is clear that increasingly more women are stepping forward to establish enterprises. In the process of entrepreneurship, women have to deal with various troubles connected with entrepreneurship and also these issues get doubled due to her twin function as a breadwinner and a housewife. Women in Czech Republic comprise a bigger proportion of the overall unemployed population and also for this reason it is essential to discover the business constraints faced by them.

\subsection{Review of Literature}

Dvouletý (2019) Although there is a rich discussion concerning entrepreneurship as well as its influence on economic advancement, a lot less is known about the real degrees of the business task. The main goal of the post is, therefore, to map the level of business activity in the Czech Republic, its framework, and development during the years 2005-2017. The research study is based on the second information acquired from national architectural service data, the International Entrepreneurship Monitor, as well as the Labour Pressure Survey. The ordinary rate of business tasks in the Czech Republic was $15.2 \%$ of the economically active population aged 15-64 years throughout the evaluated duration. The activity is controlled by solo-self-employed employees (own-account workers). Job makers stand for only $3.2 \%$ of the economically energetic population. Patterns and also mates of entrepreneurs were identified regarding gender, age, as well as education. There were 2.5 times a lot more freelance men contrasted to females for the previous years, and the proportion of job developers is likewise higher for men. The Czech job creators get on typical older (primarily represented in age associate 40-49 years) compared to solo-self-employed (mainly stood for in age accomplice 35-44 years) and they have actually acquired tertiary education and learning to a bigger level. Classification and tracking of the Czech business activity could serve as an overview for Czech policymakers as well as regional scholars. Specifically from a task production perspective, it may be really appropriate to understand the features of those individuals that use various other workers, besides themselves. From a worldwide point of view, this research may serve as a motivation to lose more light on the nationwide levels of entrepreneurship and selfemployment.

Belas, et al(2015) studied about the definition and comparison of the existing service setting of the Czech and Slovakian SMEs in the chosen regions are the primary goals of the post. Based on these objective motivational elements, conditions in the society, connection to the state, degree of corruption, approaches to loan funding, as well as a business positive outlook in the business setting have actually been examined. Carefully, there have been measured the differences between the trading firms as well as the others, in between the firms over one decade old and the others, as well as in between the micro-enterprises and the others. There were compared the point of view of business owners that specified that their primary inspiration to start an organization was cash to the point of view of various other entrepreneurs. Our study has generated intriguing findings. It was figured out that money is a vital intention for starting a service, although there are some local distinctions in this field. Entrepreneurs negatively view the connection between surroundings and also their activities, the relationship of the state to the business, and corruption that they run into while doing their company tasks. The businessmen rather criticized the financial institutions' technique of banks to fund their demands as well as at the same time they revealed a lot of company 
positive outlook.

\subsection{Statement of the problem}

Women development is a vital stimulant for rapid financial development since they constitute fifty percent of the populace of the country. And also to sustain and also maintain an anticipated financial boom, the country requires completely mobilizing and also utilizing all its sources including personnel. Due to the limitations of government policies as well as with the growth of business chances in the nation, many organizations of women entrepreneurs have actually originated; to help and creating a harmonious ambiance for the development of entrepreneurship in urban and rural areas.

\subsection{Women Entrepreneurs in Czech Republic}

Barber III, et al (2020) Business and Professional Women (BPW) Czech Republic is a branch of BPW International, a worldwide networking organization that combines 28000 women entrepreneurs, businessmen, and experts from over 90 countries, helping them attain their complete potential both in the work environment as well as in public life. Participants of BPW take advantage of a worldwide network of like-minded women, enjoyable and also thoughtprovoking events, training, awards, and also an acknowledgment, attention, as well as brand-new service possibilities. BPW subscription is open to females of every age regardless of their career. The BPW Czech Republic runs a mentoring program as well as arranges routine occasions advertising equality between women and also men in society. Overall, self-employment and entrepreneurship rates in the Czech Republic are above the European Union (EU) average. This is specifically true for youth that was far more likely than the EU standard to be proactively functioning to start a company or managing a brand-new one throughout the 2013-17 duration (11.5\% vs. 7.7\%). Over the very same period, male candidates were far more likely than females to be associated with starting or handling a brand-new organization (11.5\% vs. $4.7 \%)$, and also this gap is higher than in a lot of EU countries.

\subsection{Objectives of the study}

1) To check out the group account of women small business owners in the Czech Republic.

2) To probe into restrictions faced by females business owners to start up their very own business.

3) To supply suggestions to boost the satisfaction of females entrepreneurs.

4) To examine the socio-economic problems of the women entrepreneurs in the Czech Republic.

5) To assess the aspects of the economic empowerment of women business owners in the Czech Republic.

\section{Methods}

This study is focus on primary data and secondary data. The primary data were collected from 100 women entrepreneurs in the Czech Republic through structured questionnaire. The data was collected through appropriate sampling method. The secondary data were collected from books, journals, newspapers and website to develop theoretical background of problems of rural women entrepreneurs.

\section{Result and Discussions}

\subsection{Analysis and Interpretation}

This study is aims at economic empowerment of Women Entrepreneurs in the Czech Republic. For this purpose the study was conducted for 100 respondents of the women entrepreneurs in the Czech Republic. An attempt has been made in this section to analyze the collected data with reference to activities of the women entrepreneurs a detailed analysis are given below. 
Table 1 Age of the respondent

\begin{tabular}{|c|c|c|}
\hline Age & $\begin{array}{l}\text { No. of Respondents } \\
(\mathrm{n}=100)\end{array}$ & Percentage $(\%)$ \\
\hline 20 years & 22 & $22 \%$ \\
\hline 21-30 years & 35 & $35 \%$ \\
\hline $31-40$ years & 20 & $20 \%$ \\
\hline $41-50$ years & 23 & $23 \%$ \\
\hline TOTAL & 100 & $100 \%$ \\
\hline
\end{tabular}

From the table 1, reveal that out of 100 women entrepreneurs in the Czech Republic, $35 \%$ of the respondents are under the age group of 21-30 years, $23 \%$ of the respondents are under the age group of 41-50 years, followed by $21 \%$ of the respondents are under the age group of below 22 years, $20 \%$ of the respondents are under the age group of 31 40 years. Majority of the respondents are under the age group of 21-30 years.

Table 2 Marital status of the respondent

\begin{tabular}{lcc}
\hline \multicolumn{1}{c}{ Marital Status } & $\begin{array}{c}\text { No. of Respondents } \\
(\mathrm{n}=100)\end{array}$ & Percentage (\%) \\
\hline Single & 28 & $28 \%$ \\
Married & 48 & $48 \%$ \\
Widow/ Divorced & 24 & $24 \%$ \\
TOTAL & 100 & $100 \%$ \\
\hline
\end{tabular}

From the table 2, shows that $48 \%$ of the respondents are married, $28 \%$ of the respondents are unmarried, and rests of the 24 respondents are Widow / Divorced. Majority of the respondents are married.

Table 3 Educational Qualification of the Respondent

\begin{tabular}{lcc}
\hline \multicolumn{1}{c}{ Educational Qualification } & $\begin{array}{c}\text { No. of Respondents } \\
(\mathrm{n}=100)\end{array}$ & Percentage (\%) \\
\hline Higher schooling & 35 & $35 \%$ \\
Certificate Courses & 28 & $28 \%$ \\
Under Graduate & 25 & $25 \%$ \\
Post Graduate & 12 & $12 \%$ \\
TOTAL & 100 & $100 \%$ \\
\hline
\end{tabular}

From the table 3 reveal that $35 \%$ of the respondents are completed up to Higher Schooling, followed by $28 \%$ of the respondents are completed Certificate Courses, 25\% respondents are completed under graduate, $12 \%$ of the respondents are completed post graduate. The researchers conclude that Majority of the respondents are completed up to Higher Schooling candidates.

\begin{tabular}{|c|c|c|}
\hline \multirow{6}{*}{ Occupation } & No. of Respondents $(n=100)$ & Percentage $(\%)$ \\
\hline & Beauty parlor & 40 \\
\hline & Bouquet Shop & 16 \\
\hline & Dress makers & 24 \\
\hline & Jewellery makers & 16 \\
\hline & Total & $100 \%$ \\
\hline \multirow{6}{*}{ Work Experience } & No. of Respondents $(\mathrm{n}=100)$ & Percentage $(\%)$ \\
\hline & Below 5 Years & 46 \\
\hline & 6-10 Years & 33 \\
\hline & $11-15$ Years & 10 \\
\hline & Above 15 Years & 11 \\
\hline & Total & $100 \%$ \\
\hline
\end{tabular}

From the table 4 reveal that $40 \%$ of the major respondents are mentioned beauty parlor business and their major work 
experience $46 \%$ of the respondents mentioned in below five years.

Table 5 ANOVA Test (Analysis of Variance of Demographic profile Vs Environmental Constraints)

\begin{tabular}{|c|c|c|c|c|c|c|c|}
\hline \multirow{2}{*}{$\begin{array}{c}\text { Profile } \\
\text { Variables }\end{array}$} & \multicolumn{7}{|c|}{ Environmental Constraints } \\
\hline & Variance & $\begin{array}{l}\text { Sum of } \\
\text { Squares }\end{array}$ & D.F & $\begin{array}{c}\text { Mean } \\
\text { Square }\end{array}$ & F-Statistics & $\mathrm{Sig}$ & Remarks \\
\hline \multirow[t]{2}{*}{ Age } & $\begin{array}{l}\text { Between } \\
\text { Groups }\end{array}$ & 5.105 & 2 & 3.012 & 7.210 & 0.01 & Reject $\mathrm{H}_{0}$ \\
\hline & $\begin{array}{l}\text { Within } \\
\text { Groups }\end{array}$ & 100.208 & 97 & 0.315 & & & \\
\hline \multirow[t]{2}{*}{$\begin{array}{l}\text { Marital } \\
\text { Status }\end{array}$} & $\begin{array}{l}\text { Between } \\
\text { Groups }\end{array}$ & 9.568 & 2 & 4.123 & 8.349 & 0.02 & Reject $\mathrm{H}_{0}$ \\
\hline & $\begin{array}{l}\text { Within } \\
\text { Groups }\end{array}$ & 116.752 & 97 & 0.427 & & & \\
\hline \multirow[t]{2}{*}{$\begin{array}{l}\text { Educational } \\
\text { Qualification }\end{array}$} & $\begin{array}{l}\text { Between } \\
\text { Groups }\end{array}$ & 8.205 & 2 & 5.051 & 9.517 & 0.01 & Reject $\mathrm{H}_{0}$ \\
\hline & $\begin{array}{l}\text { Within } \\
\text { Groups }\end{array}$ & 116.841 & 97 & 0.305 & & & \\
\hline \multirow[t]{2}{*}{ Occupation } & $\begin{array}{l}\text { Between } \\
\text { Groups }\end{array}$ & 11.201 & 2 & 6.067 & 10.406 & 0.02 & Reject $\mathrm{H}_{0}$ \\
\hline & $\begin{array}{l}\text { Within } \\
\text { Groups }\end{array}$ & 185.221 & 97 & 0.284 & & & \\
\hline \multirow[t]{2}{*}{$\begin{array}{l}\text { Work } \\
\text { Experience }\end{array}$} & $\begin{array}{l}\text { Between } \\
\text { Groups }\end{array}$ & 9.256 & 2 & 5.297 & 5.647 & 0.01 & Reject $\mathrm{H}_{0}$ \\
\hline & $\begin{array}{l}\text { Within } \\
\text { Groups }\end{array}$ & 115.224 & 97 & 0.381 & & & \\
\hline
\end{tabular}

$\mathrm{H}_{0}$ : There is no significant between demographic variables and Environmental Constraints.

$\mathrm{H}_{\mathrm{a}}$ : There is a significant between demographic variables and Environmental Constraints.

From the table 5, it is the factor Environmental Constraints is significant with demographic profile variables. Hence it is concluded that there is a significant between Environmental constraints and the demographic profile variable of age, marital status, educational qualification, Occupation and work experience.

\subsection{Major Findings}

[1] Majority of the respondents are between the age group of 21-30 years.

[2] Majority of the respondents are married.

[3] Majority of the respondents are up to Higher Schooling.

[4] It is revealed that the factor Environmental Constraints is significant with demographic profile variables. Hence it is concluded that there is a significant between the constrainable factor of Environmental constraints and the demographic profile variable of age, marital status, educational qualification, occupation and work experience. 


\subsection{Suggestions for environmental constraints}

1) Abdul Rahim, et al (2017) A lot of the women business owners are stating that the absence of training is the major issue in their service. Hence, the Federal Government, NGOs, and also incubation training center ought to perform the often training provided to the rural women business owners.

2) An additional crucial significant trouble is money. So the federal government reveals the credit center to the entrepreneurs without huge rules and also treatments.

3) Married women are encountering enormous problems on the household side and in addition to culture, so women business owners need to be urged and inspired to do their own interested organization.

4) García-Lomas \& Gabaldón (2018) Women business owners are half of the nation for expanding economic development, develop a course to develop total financial empowerment in the world.

5) Advertising and marketing product is just one of the major issues for women business owners. Below, Women co-operative societies can be started to procure the products from women business owners. They will help them in selling their items at a sensible rate.

6) Improper area, as well as insufficient infrastructure centers, are the difficulties in the method of growth of women entrepreneurship. Therefore, separate commercial estates may be set up specifically for women entrepreneurs to lower the first financial investment and also to produce a unique atmosphere.

\section{Conclusions}

Women's entrepreneurship is both regarding women's placement in society as well as concerning the duty of entrepreneurship in the exact same Society. Women business owners encountered lots of challenges particularly in MSMEs and Small business enterprise that need to be overcome in order to provide accessibility to the exact same possibilities as men. Especially the access of country females into the micro businesses will be encouraged as well as worsened. The rural women are having fundamental aboriginal expertise, Skill, potential, and sources to establish and take care of the enterprise. Women entrepreneur networks are significant resources of expertise about women's entrepreneurship and also they are significantly recognized as an important tool for its growth as well as promotion. This will encourage other country women to participate in micro-entrepreneurship with the appropriate aid and they can reinforce their capabilities besides adding to the family revenue and also national productivity.

Women in the Czech Republic currently have the perspective to grab the chances. All they require currently is the platforms to showcase their talent. Women business owners deal with so many problems in aspects of financial, marketing, health and wellness, family, and also problems. Women today are happier to take up activities that were once considered the preserve of male, and also have verified that they are second to no one with respect to the payment to the development of the economic climate. As federal government motivation and assistance is very crucial to women entrepreneurs imply while family members' assistance is also really crucial for the development of such business owners.

This research takes a look at the problems encountered by women entrepreneurs in the Czech Republic at numerous degrees in their journey as an entrepreneur, even more; the research likewise tries to go through into the elements inspiring these women to come to be an entrepreneur as well as suggests a structure for the chances of women entrepreneurship. It's been located in the study that Women business owners deal with great deals of problems like duty dispute, absence of motivation, absence of financing, maintaining job life balance, differentiating therapy, understanding government regulations as well as policies, and so on. For a few of the factors encouraging to start their own business is to support households financially, while for some of them it is the urge to be economically independent. The appropriate type of support from family members, society as well as Government can make these Women Entrepreneurs one of the vital entrepreneurial source as well as they can contribute in the direction of the economic and social advancement of the Czech Republic. 


\section{References}

Abdul Rahim, I. H., Fabeil, N. F., \& Sung, T. P. (2017). Motivator and Challenges of Women Entrepreneurs. Journal of Global Business and Social Entrepreneurship, 1(3), 111-121.

Barber III, D., Batchelo, J. H., Hatten, T., Gibson, S. G., \& Rolínek, L. (2020). Czech Students' Perceptions of Ethical Behavior in Business and Entrepreneurship. Business Ethics and Leadership, 4(1), 80-91. https://doi.org/10.21272/bel.4(1).80-91.2020

Belas, J., Bilan, Y., Demjan, V., \& Sipko, J. (2015). Entrepreneurship in SME segment: case study from the Czech Republic and Slovakia. Amfiteatru Economic Journal, 17(38), 308-326.

Belás, J., Dvorský, J., Tyll, L., \& Zvaríková, K. (2017). Entrepreneurship of university students: Important factors and the propensity for entrepreneurship. Administratie Si Management Public, 2017(28), 6-25.

Belas, J., Gavurova, B., Korony, S., \& Cepel, M. (2019). Attitude of University Students toward entrepreneurship environment and toward entrepreneurship propensity in Czech Republic and Slovak Republic-International Comparison. Economic Research-Ekonomska Istrazivanja, 32(1), 2500-2514. https://doi.org/10.1080/1331677X.2019.1615972

Dvouletý, O. (2019). Development of entrepreneurial activity in the czech republic over the years 2005-2017. Journal of Open Innovation: Technology, Market, and Complexity, 5(3), 38.

García-Lomas, I., \& Gabaldón, P. (2018). Women's participation in social enterprises: a review of the literature. In RENT 2018 - Research In Entrepreneurship And Small Business (p. 27). Retrieved from http://www.eiasm.org/documents/abstracts/58447.pdf

Lukeš, M. (2017). Entrepreneurship development in the Czech Republic. In Entrepreneurship in Transition Economies (pp. 209-224). Springer, Cham. 